\title{
SOCIAL CAPITAL AND THE CAMPUS COMMUNITY
}

\author{
Andrew N. Carpenter, Ellis University \\ Linda Coughlin, St. Mary's College of Maryland \\ Susanne Morgan, Ithaca College \\ Christopher Price, The College at Brockport, \\ State University of New York
}

Investigating colleges' and universities' social capital through its five dimensions-civic engagement, norms and trust, collective action, bonding capital, and bridging capital-provides a powerful way of thinking about organizational and faculty development. Four very different institutions of higher learning have promoted their organizational development through efforts that build social capital. We seek to inspire additional application of and research into this topic by demonstrating that confronting the complexities of social capital within diverse campus communities can help faculty developers understand those communities with greater nuance and in ways that improve their ability to design and implement development initiatives.

The study of social capital is most developed in political science, economics, sociology, and community organizing. We submit that the concepts underpinning social capital and its effects on community have value for institutions of higher learning as they develop their organizations and, especially, their faculty. Thus, the question that inspires this chapter is: Might a thorough understanding of the dynamics of social capital allow us to understand our organizations' development potential and give us tools for building stronger communities on our campuses? 


\section{The Fundamentals of Social Capital}

The metaphor of capital has been used in a variety of contexts. Financial capital is money available for investment; physical capital is real estate, equipment, and infrastructure; human capital is in training that increases productivity on the job; and cultural capital involves in-depth cultural knowledge that can be turned to the owner's socioeconomic advantage (Light, 2004).

A social capital economy can be understood as a system similar to that of a financial economy. A financial economy is based on the exchange of money, and financial capital is the accumulation of financial resources. A social capital economy is based on exchanges between and among people who form social relationships. In the social capital system, the currency is the trust and shared norms of the relationships, and the wealth is social networks.

Theories of social capital investigate how relationships of trust embedded in social networks (Light, 2004) support individuals' and groups' productivity and capacity to plan future action and achieve collective aims. In Farr's (2004) useful characterization, "Social capital is . . conceptualized as the network of associations, activities, or relations that bind people together as a community via certain norms and psychological capacities, notably trust, which are essential for civil society and productive of future collective action or goods" (p. 9). A key assumption of this chapter is that faculty developers have much to gain by understanding the network of associations operative in their own institutions and by conducting faculty development activities that contribute to social capital. The results can be improved faculty productivity, increased student learning, and a greater institutional capacity to learn and improve.

Before discussing these themes with respect to our diverse institutions, we pause to reflect that the contemporary concept of social capital has a long intellectual history and pedigree that includes work on political economy by philosophers Jeremy Bentham and Henry Sidgwick, work on social structures by Max Weber and Emile Durkheim, and work on democracy and education by John Dewey (Farr, 2004). Farr identified the first use of the term social capital by Karl Marx in 1867, but the intellectual history of the concept has much deeper philosophical roots. Marx's use of the term drew heavily on Aristotle's conception of humans flourishing within a social context. Aristotle used the concepts of friendship (philia) and political community (zoon politicon) to understand the structures of society and political economy and their relationship to individuals' ability to develop their capacities through action in social and political contexts (Gilbert, 1981; McCarthy, 1990). 
Most recently, the concept of social capital has gained visibility in the United States through the well-known book Bowling Alone: The Collapse and Revival of American Community (Putnam, 2000), which applied Putnam's prior definition of social capital as "social organization such as networks, norms, and social trust that facilitate coordination and cooperation for mutual benefit" (Putnam, 1995, p. 67). Rohe (2004) articulated the dynamics of the social capital system by suggesting that a person who engages in civic life builds social networks from which relationships of interpersonal trust develop. Environments rich in networks of reciprocal relations are likely to be able to engage in effective collective action, and that action increases benefits for both the individual and the social organization. Completing the cycle, increased individual and social benefits are likely to prompt increased civic engagement. Other theorists have distinguished two forms of social capital: bonding capital, which brings together people who already know each other, and bridging capital, which connects people who previously did not interact (Vidal, 2004).

It is with these concepts that we analyze efforts to build and exploit social capital at our own institutions. We start by noting that increasing individuals' engagement in the community, for example, by joining or forming social networks, can build interpersonal trust. Putnam (2000) and others suggest that the reciprocal nature of the relationships within social networks increases interpersonal trust. An organization in which social networks exist is better able to engage in collective action to achieve common objectives, in part because of shared norms and thus common goals. Effective collective action can bring benefits to both individuals and the organization. Thus, both individual and organization become wealthier in social capital when there is a higher level of social engagement, and individuals and organizations are likely to increase their social capital further through shared goals and actions. This characteristic of social capital, that new capital can be created, differentiates it from the financial capital system (Light, 2004). That said, there are significant relationships among the various types of capital; for example, the absence of ready financial capital during a time of economic troubles may spur institutions to focus on developing their social capital. Institutions may find that using social capital to fuel collective action may help them cope with difficult financial situations.

\section{Social Capital and the Campus Community}

Building community is important in higher education, and concern with community is evident in discussions of student life (Kuh, Kinzie, Bridges, \& Hayek, 2007), institutional well-being (Keeling, 2004), and teaching 
and learning (Fink, 2003). Community is also central in efforts to enhance faculty experience through faculty learning communities (FLCs) (Cox \& Richlin, 2004) and through wider intellectual exchange as promoted by the Carnegie Foundation for the Advancement of Teaching and Learning in their Learning Commons project (Hutchings \& Huber, 2005).

Our analysis and application of social capital to institutions of higher learning is informed by the contributors to a symposium on social capital in the Journal of the American Planning Association (Hutchinson et al., 2004). We submit that the work of community planners is similar to the work of faculty developers, both of whom engage in organizational development from a basis in theoretical and applied research. We also note that our purpose here is akin to that of the planners' symposium, which sought "not to consider social capital as a societal phenomenon, but to explore whether this concept could provide valuable insights, approaches, and tools for planners" (Hutchinson, 2004, p. 144).

In higher education, the concept of social capital has been used directly and indirectly. Cox (2004) reported findings from Putnam's book when he emphasized the importance of community and the value of faculty learning communities (FLCs). Participants in successful FLCs build social capital as they form bonds with each other, establish shared norms, and engage collectively in common scholarly activity. FLCs benefit both the individual faculty member and the institutional culture. We suggest that analyzing these communities in terms of the specific dimensions of social capital could be helpful in maximizing their potential.

Writers such as Boice (2000) urge new faculty to become engaged in their campus communities, and although they seldom mention social capital directly, they imply that civic engagement will help faculty learn norms and build relationships of trust. Boice's research on successful new faculty members has demonstrated that "quick starters" build social capital more effectively than their peers do. A systematic examination of these findings in terms of the dimensions of social capital would be an intriguing way to guide faculty development efforts.

The strong networks formed intentionally by the Professional and Organizational Development Network in Higher Education (POD) serve to increase bridging capital when leading scholars engage with newcomers at conferences and online. Similarly, the Carnegie Foundation for the Advancement of Teaching's advocacy of a teaching and learning commons can be seen as an effort to build bonding capital among faculty worldwide. 


\section{Building Social Capital at Four Institutions of Higher Learning}

The concept of social capital has been valuable in understanding faculty and organizational development efforts on the campus of each chapter author. Our case studies examine with a new lens-that of building social capital-recent development initiatives at our own institutions. In this chapter, therefore, we are applying the principles of social capital in retrospect by teaching ourselves new insights about what has already occurred. We hope that these insights will inspire readers both to design initiatives that involve social capital building activities and engage in scholarship that applies and extends the principles of social capital development to academic communities.

\section{Ithaca College}

Ithaca College is a midsized private comprehensive college with six thousand undergraduates in five schools and a few hundred students in professional graduate programs. There is no collegewide curricular requirement for students, and the 450 full-time faculty members have been quite isolated in their schools. Institutional faculty development efforts have been decentralized, and despite a large budget for individual faculty grants, a faculty member assigned half-time provides the only regular support for individual and organizational development. Into this environment came a new president, provost, and deans of influential schools.

Assessing the well-being of the faculty, these new administrators identified several challenges that relate to social capital. Isolation is typical of much of faculty work; in most disciplines, both teaching and research are individualized, and there is little incentive to work collaboratively. As elsewhere in higher education, the rapid growth of the college in the 1970 s created a particular shared faculty identity. The incoming faculty generation does not share the old identity and does not experience an allcollege faculty culture.

Anxiety about tenure is high among newer faculty, who sense shifting norms but do not have clear information. The school and college administrations are clear that effective teaching employs methods other than lecture and discussion, that interdisciplinary or integrative learning is critically important, and that continued scholarship is expected of new faculty. However, the middle level, those who review faculty in the departments and schools, are often overly cautious about such contemporary views of faculty work. 
Faculty governance is uneven across the college, and there is no clear faculty voice about curriculum and policy. Particularly in the liberal arts school, the largest, faculty are typically far removed from important decisions. Very few faculty members engage in all-college governance activities and when they do, it may be with a sense of futility.

Each of these challenges-a culture of faculty isolation, anxiety about reviews and tenure, and weak faculty governance-points to a pervasive problem of weak social capital. Recent efforts by the faculty development coordinator, the deans, and the president are addressing social capital concerns.

For several years, groups of faculty have built trusting relationships through the all-college mentoring program and tenure seminar. In each of these programs, small faculty groups increase shared norms and reduce isolation and anxiety. The mentoring program consists of small, diverse groups of faculty whose explicit objective is immersion in the campus culture. Approximately one-fourth of the faculty has participated at least once, and they report that the reciprocal nature of the relationships is the major benefit. Faculty at all levels gain insights into other disciplines, new approaches to teaching, and understanding of the college culture. At least five collaborative teaching or research projects have emerged from mentoring groups.

The goal of the tenure seminars, more content oriented than the mentoring groups, is to demystify the tenure process and help faculty create more nuanced analyses of their work. In part, the tenure seminar program has been a "subversive" effort to improve the reviews conducted by committees and department chairs. As junior faculty expand the issues they include in their self-evaluation, they lead their reviewers to address those issues. This collective action by newer faculty is gradually shifting the college's norms and increasing the capacity for effective reviews.

Administrators also support effective collective action from the top; the new president and the dean of the largest school are actively revitalizing faculty governance. The resulting shared social networks affirm the emerging institutional norms and strengthen the social capital of both individuals and administrative units.

An intentional focus on increasing social capital produced the Ithaca Faculty Commons, a new faculty development model designed to maximize resources in a period of budgetary constraint. At the request of the new provost, faculty developed a plan to coordinate the many existing faculty development efforts within a blended online and face-to-face environment. Web 2.0 tools are central to the Faculty Commons, which builds engagement by directing faculty into a sophisticated suite of social 
networking and other Web-based tools. Individual faculty and staff post the faculty development activities or resources of their committees, offices, or projects. Faculty conduct or archive discussions and presentations through the evolving campus online social networking environment. Faculty engagement drives the success of this model, and the relationships that develop will be an additional benefit.

Bonding and bridging capital also guide faculty and organizational development. With the generational transition, bonding capital is very important. A culture of mistrust of administration and of factions within departments is diminishing as newer faculty members perceive themselves as institutional citizens in addition to disciplinary teacher-scholars. Intentional and increased use of the Web environment increases bridging capital by linking people across status and divisions. For instance, the president is a regular participant in the online social community.

Ithaca College expects that intentionally increasing social networks to build reciprocal trusting relationships will bring benefits for individuals and the institution by increasing faculty retention and effectiveness and increase faculty engagement in the life of the institution.

\section{St. Mary's College of Maryland}

St. Mary's College of Maryland is a small, public, liberal arts honors college with two thousand undergraduates and a single graduate program (master of arts in teaching). In a series of faculty discussions of the mission of the college held in 2003 , weak organizational communication emerged as a primary issue, and academic excellence was affirmed as the main priority. Online postings of the groups' ideas led to wider discussions and promoted trust in a common goal. Over the next five years, faculty vigorously discussed proposals in small groups and large forums that produced changes in faculty governance and in tenure and promotion processes, and a new core curriculum. The governance changes streamlined multiple campus committees into standing faculty senate committees that now have student and administrative staff membership. These structures allow thorough and speedy review and critique of policies and processes, providing bridges between groups that had seldom discussed these issues before.

As a result of the governance changes, responsibility for faculty development shifted from four division heads to sixteen department chairs. The chairs now meet regularly with the provost and associate provost for academic affairs to debate a wide range of cross-campus issues in a forum that builds bridging capital. Most departments have launched strategic 
plans, analyzed community standards, developed mentoring standards for both pretenure and tenured faculty, and created assessment plans for their curricula.

Intentional efforts to enhance social capital began in 2006 with weeklong teaching excellence workshops open to the entire faculty. The associate provost encouraged the education studies department to develop workshops in collaboration with other interested faculty; their engagement sparked more faculty to become leaders of discussions and active learning sessions focused on liberal arts pedagogy, classroom management, assessment, and international education. After a modest beginning, the workshops now host over 50 percent of the faculty each August. At these workshops, faculty discuss college norms for teaching, groups explore new teaching ideas, and trust builds among group members who normally do not interact to discuss ideas and devise strategies for teaching.

A senior faculty member working with two pretenure faculty developed a new faculty seminar that allows faculty to share their first-year teaching experiences with peers. The organizing group asked the provost for stable funding to ensure its continuation. New faculty meet monthly, visit classrooms of peers and more experienced colleagues, develop group norms and bond in the seminar setting, and become fully engaged in the campus community much earlier than previous cohorts did. The cohorts go on to work together to complete their tenure and promotion portfolios.

The new core curriculum led faculty to collectively study ways to teach four liberal arts skills effectively throughout the curriculum. At the genesis of the new core curriculum, faculty called for more faculty development to build teaching and assessment skills in the newly instituted first-year seminars. The yearly cohort of first-year seminar teachers now brings their experience from the first-year seminars back to their departments to strengthen student skill building in the majors. Such collective action has resulted in an online handbook that outlines best practices and useful examples of pedagogy for critical thinking, oral and written communication, and information literacy across the curriculum.

Collective action led to a major revision of the faculty handbook that now contains previously missing descriptions of academic responsibilities and the processes linked to them, as well as a section of community standards that outlines in one place our former unwritten norms. All committees, both administrative and faculty, post minutes, agendas, and background materials on a campus portal. The administration often asks for written feedback on proposed initiatives and publishes anonymous 
surveys of opinions and preferences. All handbooks for the faculty, students, board of trustees, and department chairs are available for everyone to read in our online portal.

Each of these major changes occurred by building bridging capital. Small groups of faculty, students, and staff were organized into discussion groups by the faculty senate working with the provost's office. Faculty from disparate departments were intentionally placed together in the groups. The discussions that ensued were richer because they bridged the concerns of multiple campus groups. The linking of campus groups to each other and to authority has engaged the community in the decisionmaking process, increased communication, transparency, and trust and has made community norms explicit.

\section{Ellis University}

In 2009 , the first full year of this private, nonprofit, and exclusively online university's operation, Ellis University undertook a series of organizational development initiatives focused on improving the institution's decision-making processes. First, it implemented an institutional model to make its decision making more transparent. Second, it created processes and tools to ensure that its new strategic plan, which was developed by the institution's administration, faculty, and staff, made strong and transparent connections to other policy, decision making, and budgeting systems. Third, the university created a shared governance agreement, and fourth, it created a new faculty senate constitution, both of which its trustees adopted. Taken together, the initiatives helped the institution to make decisions that are data driven, collaboratively achieved with input from essential personnel across the institution, and responsive to the needs of students and other stakeholders. This is why many within the institution considered these initiatives significant milestones in Ellis University's early development; in particular, many faculty and administrators viewed their successful completion as a vital indicator of the new institution's ability to direct its own development, foster innovation, and enhance institutional assessment.

Each of these initiatives also served to build social capital. With respect to norms and trust, the initiatives were intentionally built on the core values that inspired the founding of the institution: educational quality, academic rigor, and institutional integrity. Successful work on the four initiatives increased trust among participants, because their successes reaffirmed key norms and core values and the initiatives involved inclusive and democratic collective action. 
The inclusive nature of the initiatives also created a significant opportunity to develop bridging capital. For example, planning and drafting a comprehensive shared governance agreement required substantive discussions among many adjunct and full-time faculty, and between members of those groups and the institution's entire academic administrative leadership. Successfully negotiating this agreement required many collegial discussions and created strong relationships among elected faculty leaders, the institution's president, and the chair of the university's board of trustees. The high level of engagement by faculty, senior administrative leaders, and trustees has served to significantly enhance social capital. For example, nearly all the faculty members involved in the negotiation of the shared governance agreement report that they now trust and respect the institution's president and trustees, and they also report that they feel trusted and respected by those institutional leaders. Likewise, adjunct faculty members involved in these initiatives report they have never felt more valued by, or more strongly connected to, an institution of higher learning to which they had no full-time connection.

In short, by developing and exploiting social capital, Ellis University has achieved a level of collegial interaction and decision making that is unusual among traditional institutions, and even rarer among online institutions. We note, however, that this institution's ambitions are tempered by the difficulty of developing social capital in an exclusively online environment. Two significant problems are that faculty are geographically dispersed, making formal and informal communication difficult, and that the faculty include many adjuncts, a group often marginalized in academic governance. The use of bonding capital provides a significant resource for working on those challenges. Its faculty interacts using a sophisticated virtual campus learning platform that includes multiple social networking functions and widespread use of Web 2.0 communication technologies like wikis and blogs. These tools allow academic stakeholders to begin to address its challenges and to draw on and build social capital as it continues to learn how to overcome them.

\section{The College at Brockport, State University of New York}

The College at Brockport is one of thirteen regional comprehensive colleges in the State University of New York system. Since 1997, the college has sought to change its identity to compete for students who traditionally would not have considered enrolling at Brockport. To help bring about this change, the college reorganized the academic affairs division in 2010, going 
from three schools to four (with a fifth to come two or three years later), in part to create a more entrepreneurial culture among the faculty and administration. These changes have caused predictable anxiety as some faculty are not certain whether or where they fit within this new plan. From a faculty and organizational development perspective, the concern is that some faculty might choose to focus more on their own career at the expense of initiatives that would increase institutional social capital. The challenge is to figure out how to help the faculty, professional staff, and administration reframe this change as an opportunity to work together to improve both their own professional development and student learning. Two initiatives already under way-faculty learning communities and programs to increase student civic engagement-are likely starting points to begin this development work.

Beginning in 2008, FLCs have been piloted as a possible model for all faculty and staff professional development initiatives. The FLC approach helps increase engagement as the participants explore their professional interests with colleagues in other departments in order to achieve individual and collective goals that have a positive impact on the college community. For example, three FLCs (on diversity, service-learning, and online learning) have given the faculty involved a sense of ownership over areas that are often top-down administration-led initiatives. FLCs have the potential to increase levels of trust among the faculty through the creation of a norm of interdepartmental collaboration. In order to make such collaboration more visible, the recently established annual teaching and learning day gives the FLC faculty an opportunity to inform colleagues outside their departments about what they are doing to improve student learning.

In 2004, Brockport joined the American Democracy Project (ADP), an initiative cosponsored by the American Association of State Colleges and Universities and the New York Times, that is focused on helping undergraduate students become better citizens. At that time, the campus undertook a civic engagement audit of both the academic curriculum and the cocurriculum (student clubs, student government activities, and other programs outside the academic departments). The audit showed that although civic engagement activities were widespread, there was little awareness among faculty and staff about what was going on outside their own departments. The effort to increase student civic engagement generated significant bridging capital as faculty worked alongside student affairs staff to strategize how to leverage what the college was currently doing to create new programs to meet the ADP goals. While Brockport 
was able to establish some initiatives (including a speaker series, a freshman summer reading program, an interdisciplinary ADP course, a student living-learning community, and a standing steering committee), the level of bridging capital generated has not been sufficient to make a significant impact on the student population. In order to achieve deeper and more sustained levels of student civic engagement, the college now has a student leadership program and is investigating the establishment of a service-learning program. These programs will require a significant amount of bonding capital among those dedicated to these projects and bridging capital between faculty and professional staff in student affairs.

\section{Summary of Institutional Social Capital Efforts}

The preceding discussion of the ways in which the concept of social capital has played out in development efforts on each author's campus is summarized in Table 15.1.

\section{Conclusions and Recommendations for Future Research}

From the examples we have discussed from our own institutions, three conclusions stand out. First, learning how to assess social capital at institutions of higher learning can provide powerful new insights into the strengths and weaknesses of development efforts. Second, learning how to identify opportunities to increase social capital may help campuses plan and prioritize future development efforts. Third, learning how to effectively use existing social capital may help developers to maximize the efficacy of their projects and interventions. However, if developers are to learn to assess and use social capital, additional scholarly work is required. In particular, there is an urgent need to design and validate methods for systematically measuring social capital at institutions of higher learning, and there exist numerous significant opportunities to construct theoretical and practical tools that faculty developers can use to assess, build, and exploit social capital at their own institutions.

Social capital is a complex concept, and one of great utility. Confronting the complexities of social capital within diverse campus communities can help faculty developers better understand those communities and thereby improve their capacity to design and to assess development initiatives. 
Table I 5.I Social Capital in Development Efforts

\begin{tabular}{|c|c|c|c|c|}
\hline & $\begin{array}{l}\text { Ithaca } \\
\text { College }\end{array}$ & $\begin{array}{l}\text { St. Mary's } \\
\text { College of } \\
\text { Maryland }\end{array}$ & $\begin{array}{l}\text { Ellis } \\
\text { University }\end{array}$ & $\begin{array}{l}\text { The College } \\
\text { at Brockport, } \\
\text { State University } \\
\text { of New York }\end{array}$ \\
\hline Type & $\begin{array}{l}\text { Private com- } \\
\text { prehensive }\end{array}$ & $\begin{array}{l}\text { Public liberal } \\
\text { arts (honors) }\end{array}$ & $\begin{array}{l}\text { Private } \\
\text { comprehensive } \\
\text { (online) }\end{array}$ & $\begin{array}{l}\text { Public } \\
\text { comprehensive }\end{array}$ \\
\hline $\begin{array}{l}\text { Number } \\
\text { of stu- } \\
\text { dents }\end{array}$ & $\begin{array}{l}6,000 \\
\text { undergradu- } \\
\text { ate and } \\
450 \text { graduate }\end{array}$ & $\begin{array}{l}2,000 \\
\text { undergraduate } \\
\text { and } 45 \\
\text { graduate }\end{array}$ & $\begin{array}{l}1,500 \text { under- } \\
\text { graduate and } \\
500 \text { graduate }\end{array}$ & $\begin{array}{l}6,900 \text { under- } \\
\text { graduate and } \\
1,400 \text { graduate }\end{array}$ \\
\hline $\begin{array}{l}\text { Number } \\
\text { of } \\
\text { faculty }\end{array}$ & $\begin{array}{l}450 \text { full time } \\
\text { and } 200 \text { part } \\
\text { time/adjunct }\end{array}$ & $\begin{array}{l}140 \text { full time } \\
\text { and } 60 \text { part } \\
\text { time/adjunct }\end{array}$ & $\begin{array}{l}11 \text { full time and } \\
275 \text { part time/ } \\
\text { adjunct }\end{array}$ & $\begin{array}{l}360 \text { full time } \\
\text { and } 270 \text { part } \\
\text { time/adjunct }\end{array}$ \\
\hline $\begin{array}{l}\text { Civic } \\
\text { engage- } \\
\text { ment }\end{array}$ & $\begin{array}{l}\text { Faculty } \\
\text { commons }\end{array}$ & $\begin{array}{l}\text { Teaching } \\
\text { excellence } \\
\text { workshops and } \\
\text { first-year } \\
\text { teachers' } \\
\text { program }\end{array}$ & $\begin{array}{l}\text { Shared } \\
\text { governance } \\
\text { agreement }\end{array}$ & $\begin{array}{l}\text { Faculty } \\
\text { learning com- } \\
\text { munities }\end{array}$ \\
\hline $\begin{array}{l}\text { Norms } \\
\text { and } \\
\text { trust }\end{array}$ & $\begin{array}{l}\text { Mentoring } \\
\text { program and } \\
\text { tenure } \\
\text { seminar }\end{array}$ & $\begin{array}{l}\text { Peer-to-peer } \\
\text { dialogue one- } \\
\text { on-one and in } \\
\text { small groups }\end{array}$ & $\begin{array}{l}\text { Open } \\
\text { communication } \\
\text { and } \\
\text { collaboration }\end{array}$ & $\begin{array}{l}\text { Interdepart- } \\
\text { mental } \\
\text { collaboration }\end{array}$ \\
\hline $\begin{array}{l}\text { Effective } \\
\text { col- } \\
\text { lective } \\
\text { action }\end{array}$ & $\begin{array}{l}\text { Tenure review } \\
\text { improvements } \\
\text { Faculty } \\
\text { governance } \\
\text { enhancements }\end{array}$ & $\begin{array}{l}\text { Faculty gover- } \\
\text { nance changes } \\
\text { Tenure and } \\
\text { promotion } \\
\text { process changes } \\
\text { New core } \\
\text { curriculum }\end{array}$ & $\begin{array}{l}\text { Six new degree } \\
\text { programs } \\
\text { Formal } \\
\text { decision-making } \\
\text { model } \\
\text { Navigation of } \\
\text { regulatory } \\
\text { challenges } \\
\text { Successful } \\
\text { regional } \\
\text { accreditation }\end{array}$ & $\begin{array}{l}\text { Academic } \\
\text { affairs reorga- } \\
\text { nization } \\
\text { Programs to } \\
\text { increase } \\
\text { student civic } \\
\text { engagement }\end{array}$ \\
\hline $\begin{array}{l}\text { Bonding } \\
\text { capital }\end{array}$ & $\begin{array}{l}\text { Recently } \\
\text { hired faculry } \\
\text { incorporated } \\
\text { as institu- } \\
\text { tional citizens }\end{array}$ & $\begin{array}{l}\text { Collaborative } \\
\text { development of } \\
\text { courses by new } \\
\text { first-year- } \\
\text { seminar teachers }\end{array}$ & $\begin{array}{l}\text { Faculty par- } \\
\text { ticipation in a } \\
\text { virtual social } \\
\text { network using } \\
\text { Web } 2.0 \text { tools }\end{array}$ & $\begin{array}{l}\text { Faculty par- } \\
\text { ticipation in } \\
\text { annual Teaching } \\
\text { and Learning } \\
\text { Day event }\end{array}$ \\
\hline
\end{tabular}

(Continued) 


\section{Table I 5.I (Continued)}

\begin{tabular}{|c|c|c|c|c|}
\hline & $\begin{array}{l}\text { Ithaca } \\
\text { College }\end{array}$ & $\begin{array}{l}\text { St. Mary's } \\
\text { College of } \\
\text { Maryland }\end{array}$ & $\begin{array}{l}\text { Ellis } \\
\text { University }\end{array}$ & $\begin{array}{l}\text { at Brockport, } \\
\text { State University } \\
\text { of New York }\end{array}$ \\
\hline $\begin{array}{l}\text { Bridging } \\
\text { capital }\end{array}$ & $\begin{array}{l}\text { Development } \\
\text { of senior- } \\
\text { junior faculty } \\
\text { relationships } \\
\text { through } \\
\text { mentoring } \\
\text { program } \\
\text { Administra- } \\
\text { tion building } \\
\text { stronger }\end{array}$ & $\begin{array}{l}\text { Administration, } \\
\text { faculty, stu- } \\
\text { dents, and staff } \\
\text { membership on } \\
\text { committees and } \\
\text { small group } \\
\text { discussions }\end{array}$ & $\begin{array}{l}\text { Interaction of } \\
\text { full-time and } \\
\text { adjunct faculty, } \\
\text { trustees, and } \\
\text { administration } \\
\text { using new sys- } \\
\text { tems of shared } \\
\text { governance }\end{array}$ & $\begin{array}{l}\text { Faculty and } \\
\text { professional } \\
\text { staff } \\
\text { participation in } \\
\text { faculty learning } \\
\text { communities } \\
\text { and student } \\
\text { civic } \\
\text { engagement } \\
\text { programs }\end{array}$ \\
\hline
\end{tabular}

\section{REFERENCES}

Boice, R. (2000). Advice for new faculty members: Nihil nimus. Needham Heights, MA: Allyn \& Bacon.

Cox, M. D. (2004). Introduction to faculty learning communities. In

M. D. Cox \& L. Richlin (Eds.), New directions for teaching and learning:

No. 97. Building faculty learning communities (pp. 5-23). San Francisco: Jossey-Bass.

Cox, M. D., \& Richlin, L. (Eds.). (2004). New directions for teaching and learning: No. 97. Building faculty learning communities. San Francisco: Jossey-Bass.

Farr, J. (2004). Social capital: A conceptual history. Political Theory, 32(1), 6-33.

Fink, L. D. (2003). Creating significant learning experiences: An integrated approach to designing college courses. San Francisco: Jossey-Bass. Gilbert, A. (1981). Historical theory and the structure of moral argument. Political Theory, 9(2), 173-205.

Hutchings, P., \& Huber, M. T. (2005). Building the teaching commons. Carnegie Perspectives. Retrieved from www.carnegiefoundation.org/ perspectives/building-teaching-commons

Hutchinson, J. (2004). Introduction. In J. Hutchinson, A. C. Vidal, R. Putnam, I. Light, X. de Souza Briggs, W. M. Rohe, et al., Using social capital to help integrate planning theory, research, and practice [Edited symposium]. Journal of the American Planning Association, 70(2), 143-144. 
Hutchinson, J., Vidal, A. C., Putnam, R., Light, I., de Souza Briggs, X., Rohe, W. M., et al. (2004). Using social capital to help integrate planning theory, research, and practice [Edited symposium]. Journal of the American Planning Association, 70(2), 142-192.

Keeling, R. P. (2004). Learning reconsidered: A campus-wide focus on the student experience. Washington DC: American College Personnel Association and National Association of Student Personnel Administrators.

Kuh, G. D., Kinzie, J., Bridges, B. K., \& Hayek, J. C. (2007). Piecing together the student success puzzle: Research, propositions, and recommendations. San Francisco: Jossey-Bass.

Light, I. (2004). Social capital's unique accessibility. Journal of the American Planning Association, 70(2), 145-151.

McCarthy, G. E. (1990). Marx and the ancients: Classical ethics, social justice, and nineteenth-century political economy. Lanham, MD: Rowman \& Littlefield.

Putnam, R. D. (1995). Bowling alone: America's declining social capital. Journal of Democracy, 6(1), 64-78.

Putnam, R. D. (2000). Bowling alone: The collapse and revival of American community. New York: Simon \& Schuster.

Rohe, W. M. (2004). Building social capital through community development. In J. Hutchinson, A. C. Vidal, R. Putnam, I. Light, X. de Souza Briggs, W. M. Rohe, et al., Using social capital to help integrate planning theory, research, and practice [Edited symposium]. Journal of the American Planning Association, 70(2), 158-164.

Vidal, A. C. (2004). Building social capital to promote community equity. In J. Hutchinson, A. C. Vidal, R. Putnam, I. Light, X. de Souza Briggs, W. M. Rohe, et al., Using social capital to help integrate planning theory, research, and practice [Edited symposium]. Journal of the American Planning Association, 70(2), 164-168. 